\title{
Distance Education and Online Learning in Thailand's Higher Education
}

\author{
Pannarat Wansavatkul Kadish \\ Suryadhep Teachers College, Rangsit University, 52347 Phahonyothin Rd, Tambon Lak Hok \\ Pathum Thani, Thailand 12000
}

\begin{abstract}
Thailand's higher education system has experienced a gradual growth of its gross enrollment ratio from $35.14 \%$ in the year 2000 to $51.3 \%$ of the relevant age group enrolled in higher education in the year 2013 (UN, UIS Data Centre). As education plays a crucial role in improving the economy of a country, opportunities wherein universities could provide the quality education, which provides the right skill set to its graduates are now being considered and explored in order to accommodate the demand of the business sector. Diversification, in terms of flexible learning methods, focuses on the delivery of these programs by the universities. While distance education is now a norm in almost all universities around the world, its presence in the Thai education system is still struggling as not all are convinced that the right skill set could be provided through this method. However, Thailand's government subsidy on distance education according to World Bank statistics (2011) is at 26.5\%, proving that the government accepted the validity of degrees earned through distance education. Distance education and online learning is not a new phenomenon but rather is becoming a necessity to increase the scope of delivery of quality education. This article will present an overview of the evolution of distance learning in Thailand, focusing on programs offered and its methods of instruction.
\end{abstract}

Keywords: Distance Education, Online Learning, Higher Education in Thailand

DOI: $10.7176 / \mathrm{JEP} / 10-21-05$

Publication date:July $31^{\text {st }} 2019$

\section{Introduction}

Universities around the world have used distance education system for many years and its effectiveness and efficiency has been analyzed and researched widely in the academe (Cooper \& Higgins, 2015; Redfern \& Naughton, 2002; Volery, T. \& Lord, D., 2000; Knight, 1996, Hawkes, M. \& Cambre, M., 2000). The growth of its users (market) has continuously risen due to social, economic, and most importantly, the technological advancements of the $21^{\text {st }}$ century. Distance education has shaped different learning behaviors and shifted learning and development as perceived today. Kentnor (2015) stated that as a method of teaching, student and teacher are physically separated. Distance education started with correspondence teaching, which then evolved to the use of media resources such as radio, television, computers, and mobile devices, in order to deliver teaching and learning materials to its users.

Although media resources enhanced the speed of delivery, it then only focused on the production and distribution of teaching and learning materials. This learning platform utilizes a virtual experience wherein direct contacts between teacher and learner or between learners are limited (Jorgensen, E., 2014) but with a broader reach. Time and location rendered insignificant as learners and teachers are technologically connected, which allows them to learn and provide learning any time, anywhere even at the comforts of their home. The technological shift in distance education enhanced the delivery and communication between its providers and users. This technological mediation between the teacher and the learner or between learners makes distance education differ significantly from the traditional learning method, with some stipulates a more significant learning outcome from its immersive interaction and environment as compared to the traditional methods of learning.

Distance education is now synonymous with online learning that uses computers and mobile devices connected to the Internet as a medium of delivery of almost $80 \%$ of the course content. Learning is proven to be more individualistic rather than a social process (Courtney, M. \& Wilhoite-Mattews, S., 2015).

\section{Distance education around the world}

Distance learning has been around since the $19^{\text {th }}$ century rooting from both Europe and the United States (United Nations Asian and Pacific Training Centre for Information and Communication Technology for Development, 2014). Since its emergence, more and more countries have adopted the distance education system as a costeffective and far-reaching delivery method of education.

In the United States, out of 18.2 million students enrolled in higher education, $21.4 \%$ or a total of 3.9 million students were enrolled with at least one online course in 2007. By 2010, students enrolled with at least one online course reached $29 \%$ of the total enrolled students in higher education $(6.1$ million students out of 21 million enrolled). In that three-year time frame, the average increase in students enrolled in at least one online course reached $18.8 \%$. By $2012,32.5 \%$ or 6.7 million students were taking at least one online class. This represents $1 / 3$ 
of the student population. Since then, educational institutions have acknowledged the need to offer online courses in order to meet the demand. According to Allen and Seaman (2015), 69.1\% of academic leaders in the US agreed that in order to sustain an educational institution's growth, online learning should be part of its long-term strategy.

The diversity in distance education offered in Europe created the challenge in gauging the total number of enrolled students under distance education. The European distance-teaching universities alone reported enrollment numbers of more than 2 million (Impact of Distance Education on Adult Learning Project, 2014). IDEAL project's research in 2014 results suggests that the main driver for distance education in Europe is the increasing demand of the (potential) students (43\%) followed by adopting a distance education model for program improvement (34\%). Hence, the availability of distance education in European HEIs has continuously increased. Over $50 \%$ of the universities in Europe offer some level of distance learning (mostly blended learning) and 9\% of the universities there are solely for distance education.

Distance education in the United Kingdom is defined into two, UK-based or UK-funded and 'solely overseas students' (students registered at a UK Higher Education Institution). There are 226,420 UK-based/funded students and 123,635 'solely overseas students' studying distance education from UK-based Higher Education Institutions in $2012-2013$. In the same period, $6.1 \%$ of undergraduate and $10.1 \%$ postgraduate 'solely overseas students' are non-European students.

Making great strides in Asia, distance education has been operated in "10 mega-universities, over 70 open universities and a growing number of conventional institutions offering DE [distance education] as well as the rapidly growing number of private and / or for-profit DE providers" (Jung, I., et al., 2011). In 2008, 3,560,000 or $12 \%$ of students in HEIs in China registered as actual distance students. Notable enrollments for distance education as of 2010 are 650,000 students in Indonesia, 13,000 students in Hong Kong, 100,000 students in Japan, over 200,000 students in Korea, 90,000 students in Malaysia, 25,000 students in Sri Lanka.

\section{Online Learning}

According to Ally (2004), online learning is defined as "the use of the Internet to access learning materials; to interact with the content, instructor, and other learners; to obtain support during the learning process, in order to acquire knowledge, to construct personal meaning, and to grow from the learning experience."

There are two types of delivery of online learning: synchronous learning and asynchronous learning. In synchronous learning, the day and time when students have to go online are indicated. Learners need to join an online class or discussion wherein they interact with the instructor as well as their peers. In asynchronous learning, students choose when they want to get access to the course materials. They are given deadlines as to when to submit course requirements such as research papers and projects. Most of the online courses now are a hybrid of these. Part of the program or course requires students to join an online class, discussion and sometimes an online exam (sometimes in a regulated environment such as testing centers) and the other part, they are free to do on their own.

Currently, we can say that online programs being offered are a mixture of traditional classroom teaching while using technological advancement in its delivery. It offers more flexibility and student participation and involvement.

\section{Advantages of online learning}

1. Borderless education - pace, place, and mode of learning is usually determined by the student. As long as there is an Internet connection, access to learning materials can easily be acquired. There is also diversity in resources to meet learners' needs and preferences.

2. Equal Opportunity - Opportunities to complete a university degree is now open for people with disabilities as the mode of delivery is easily accessible, and the pacing depends on the student. Moreover, it gives equal opportunities for students who do not have the means to study abroad. Through online classes, students will have the opportunity to interact and engage with different perspectives as students would be coming from all over the world.

3. Student-Centered - programs are flexible in those particular areas of interest, and the current needs of the industry offer. Activities that assess their progress as learners encourage them to determine their strengths, thereby giving them opportunities to match their interests with what the industry needs.

4. Autonomy - Online learning promotes self-paced learning. Learners have a choice in their education in that they get to choose which courses would best fit their needs.

5. Reasonable costs - Although the cost of online courses is not cheap when compared to traditional university fees and overhead like transportation and allowances, the fees of online courses are more economical.

\section{Online learning in Thailand}

In 2000, announced by the National IT Committee, Thailand's first National IT Policy implemented (Makaramani, R., 2013). Its goal was to utilize ICT in achieving economic prosperity and social equity, and one of the five main 
sub goals is for e-Education, including virtual education. Technological advancements in education in Thailand included in the Ministry of Education (MOE) 's ICT Master Plans. Since 2000, MOE has been securing a strong foundation of the Internet as integrated into their "Schoolnet Thailand" project. This project sparked an increase in Internet usage in teaching and learning.

Efforts of the Thai government in providing digital resources to be accessible in classrooms began in the very primary stage of education. MOE has been implementing projects after projects in its continuous support for ICT Master Plans. Remarkable outcomes such as the 2007 - 2011 Master Plan, hardware, software, and digital content for every school issued under the "Thai Kem Kang" or "Strong Thai Project. In 2008, 87.8\% of teachers in primary education had their computers spending 8.7 hours per week as an instruction tool in their classrooms, and $22.8 \%$ of their teaching materials are electronic. By 2011, most schools have an average of 50 computers available to their students and $82.02 \%$ of these computers are using the Internet. Computer usage in schools was said to be 26-50 hours per week.

The Thai Civil Service Commission first recognized a foreign degree awarded through distance education in March 2000. This acknowledgment paved the way for recognition of the legitimacy of distance education. As the gross enrollment ratio of $35.14 \%$ in 2000 increased to $51.3 \%$ in 2013, Thailand's e-learning readiness ranking went down from 36th in the world in 2003 to 49th in 2008, 2009 and 2010 (The Economist Intelligence Unit and IBM). Top rankings for eLearning readiness are the US, Sweden, and Denmark. Other Asian countries have surpassed and accepted the challenge of providing eLearning such as Hong Kong, Singapore, Japan, and Malaysia. Thailand's government subsidy on distance education is at $26.5 \%$ in 2011 .

\section{Challenges facing online learning in Thailand}

Attrition rates are much higher in online courses as students have more autonomy and control over their learning process. According to Dabbagh and Kitsantas (2004), instructors have more control over the teaching and learning environment in a traditional face-to-face classroom setting as they can monitor the progress of the students. With online learning, a warning of student motivation makes it more prone to drop-outs from the online course or program. Designing and developing practical online tools which will keep students motivated and engaged will help keep them in the program until completion.

Another challenge facing online learning is the lack of support from the faculty. Teaching skills and technological skills are two different things. A lecturer may be a very active instructor; however; a lack of technological skill set can hamper the delivery of modules to students. Barriers created by information technology for both students and the faculty (such as access to a computer, access to the Internet, access to online resources chatrooms, social networking, file sharing sites, and limited technical support for both students and the faculty) hampers the progress of online learning in Thailand.

\section{Conclusion}

In order to be successful in online learning, self-regulation, and motivation of students need to be harnessed. If students feel a lack of engagement with learning materials, they will eventually decide to stop or pursue a different course. Also, the perception of students that online courses can quickly be completed with a minimum amount of effort can pose quite a challenge to the universities offering online programs. Although online degrees are easily accessible, the quality of education delivered should not be compromised.

Connecting industry and academia has become even a more significant challenge to educational institutions nowadays. Although students have more access to acquiring their degrees online, aligning the skills set that the industry needs and the skills that they acquire should also be a match, establishing the relevance of programs. Courses offered that could provide the right skill set needed by companies is crucial to the acceptance of online degrees by companies. Currently, a student who graduates from a traditional university setting has more chances of getting hired than a graduate via online learning. As there are a lot of online degrees now which are not accredited, the word "online degree" has somewhat a negative connotation when it comes to hiring employees. In order for universities in Thailand to overcome this, collaboration with companies needed to establish a relationship with the industry. This way, courses could be molded into what the industry needs. Courses should align with the skill set, which is in demand and therefore giving better chances to their graduates when it comes to hiring. Seminars, workshops, internships, and collaborative research are some examples of this.

\section{Recommendations}

Several steps need to be undertaken in order for online programs to survive in Thailand.

Recommendations for Universities/Instructors:

- Keep courses up to date or current to maintain interest and engagement of students (create collaborative groups, occasional face-to-face video conferencing, online workshops, blogs, informal group chats). Courses should provide a diversity of resources (text, audio, video, presentations, portfolios and projects, debates) that can meet the preference of students. 
- Technical support, seminars, and workshops provided for the faculty in order to provide them with the right skills in constructing their courses.

Recommendations for the Government:

- $\quad$ Provide a scholarship for students who would like to take online courses or pursue online degrees.

- Create internship opportunities for students with online degrees.

- $\quad$ Provide more IT support in public libraries around Thailand, especially in provinces to encourage students in taking up online learning programs, as this will help alleviate IT barriers.

\section{References}

Allen, I.E., \& Seaman, J. (2015). Grade Level: Tracking Online Education in the United States. [Online] Available: http://www.onlinelearningsurvey.com/reports/gradelevel.pdf

Ally, M. (2004). Foundations of educational theory for online learning. In Terry (Ed.), The theory and practice of online learning (pp. 3-31). (2nd ed). Athabasca, AB: Athabasca University. [Online] Available: http://desarrollo.uces.edu.ar:8180/dspace/bitstream/123456789/586/1/Theory\%20and\%20Practice $\% 20$ of $\% 2$ 0online \%20learning.pdf\#page $=227$

Cooper, D., \& Higgins, S. (2015). The effectiveness of online instructional videos in the acquisition and demonstration of cognitive, affective, and psychomotor rehabilitation skills. British Journal of Educational Technology, 46(4), 768-779.

Courtney, M., \& Wilhoite-Mathew, S. (2015). From distance to online learning: Practical approaches to information literacy instruction and collaborative learning in online environments. Journal of Library Administration, 55, 261-277. doi: 10.1080/01930826.2015.1038924

Dabbagh, N., \& Kitsantas, A. (2012). Personal learning environments, social media, and self-regulated learning: A natural formula for connecting formal and informal learning. Internet \& Higher Education, 15(1), 3-8.

Hawkes, M. \& Cambre, M. (2000). The cost factor. Technological Horizons in Education, 28 (1), 26.

Impact of Distance Education on Adult Learning Project. (2014). Distance Education in European Higher Education: The Potential. [Online] Available: https://idealprojectblog.files.wordpress.com/2015/07/ideal_uk-case-study1.pdf

Jorgensen,E.R. (2014).Face-to-face and distance teaching and learning in higher education: Lessons from the preparation of professional musicians. Journal of Music, Technology \& Education, Vol.7, No.2, pp.181197(17)

Jung, I. et al. (2011). Quality Assurance in Asian Distance Education: Diverse Approaches and Common Culture. The International Review of Research in Open and Distance Learning, Vol. 12, No. 6. [Online] Available: http://files.eric.ed.gov/fulltext/EJ963932.pdf

Kentnor, H. (2015). Distance Education and the Evolution of Online Learning in the United States. Curriculum and Teaching Dialogue, Vol. 17, Nos. 1\&2. [Online] Available: http://digitalcommons.du.edu/cgi/viewcontent.cgi?article=1026\&context=law_facpub

Knight, P. (Ed). (1996). Assessment for learning in higher education. London: Kogan Page, SEDA Series.

Makaramani, R. (2013). UNESCO-RCD at SSRU, Thailand, ICT in education country report. UNESCO Resource Training and Distribution Centre Regional Seminar, 9-11 October 2013. [Online] Available: https://independent.academia.edu

Redfern, S. \& Naughton, N. (2002). Collaborative virtual environments to support communication and community in Internet-based distance education. In Proceedings of the Informing Science and IT Education, Join International Conference (pp. 1317-1327). Cork, Ireland.

The Economist Intelligence Unit and IBM. (2009). E-readiness rankings 2009 the usage imperative. [Online] Available: https://graphics.eiu.com/pdf/E-readiness\%20rankings.pdf

The World Bank. (2011). World Development Indicators. [Online] Available: http://siteresources.worldbank.org/DATASTATISTICS/Resources/wdi_ebook.pdf

United Nations Asian and Pacific Training Centre for Information and Communication Technology for Development. (2014). Open and Distance Learning in Asia and the Pacific. [Online] Available: https://www.google.co.th/url?sa=t\&rct=j\&q=\&esrc=s\&source=web\&cd=10\&cad=rja\&uact=8\&ved=0ahU KEwjui-

2VotDRAhUZTo8KHRENBjwQFghIMAk\&url=http\%3A\%2F\%2Fwww.unapcict.org\%2Fecohub\%2Fapci ct-case-study-series-open-and-distance-learning-odl\%2Fat download\%2Fattachment $1 \&$ usg=AFQjCNEn4lzoMKsi0UQrliFCwKTLNEFzw\&bvm=bv.144224172, $\overline{\mathrm{d}} . \mathrm{c} 2 \mathrm{I}$

United Nations Educational, Scientific and Cultural Organization Institute for Statistics. (2017). [Online] Available: http://data.uis.unesco.org/

Volery, T. \& Lord, D. (2000). Critical success factors in online education. The International Journal of Education Management, 14 (5), 216 - 223.

4International Colleges \& Universities (2016). Retrieved from 4ICU.ORG. 